\title{
Promoter occlusion prevents transcription of adenovirus polypeptide IX mRNA until after DNA replication
}

\author{
Lynne D. Vales and James E. Darnell, Jr. \\ The Rockefeller University, New York, New York 10021 USA
}

\begin{abstract}
The left end of the adenovirus genome is arranged such that the polypeptide IX gene is 'buried' (entirely contained) within the E1B transcription unit. The E1B gene is transcribed actively early in infection while, in contrast, IX gene transcription only occurs after DNA replication. Using recombinant plasmid constructs and recombinant viruses, we have found that the nested arrangement of the IX gene prevents its transcription. The experiments show that E1B transcription across the IX promoter inhibits IX gene expression early in infection, and yet, the 21-kD E1B protein activates the IX gene. IX mRNA synthesis occurs in the absence of DNA replication when the E1A gene and E1B promoter are absent, but only when the 21-kD E1B protein is present in trans. Our results indicate that during the adenovirus infectious cycle, the only templates on which IX transcription can be activated are newly replicated templates not committed to E1B transcription. This situation may be a model for genes that are activated specifically at the time of replication.
\end{abstract}

[Key Words: Transcription; overlapping genes; promoter occlusion; positive activators]

Received August 30, 1988; revised version accepted December 3, 1988.

In addition to providing key information regarding mRNA biosynthesis and post-transcriptional regulation, the study of adenovirus mRNA formation has also revealed various aspects of transcriptional regulation in animal cells (for review, see Pettersson and Roberts 1986). Temporal control of initiation at different transcription units [including the protein IX transcription unit (Wilson et al. 1979) controlled termination of the long major late transcription unit (Nevins and Wilson 1981), as well as secondary activation of a set of viral genes by the action of the protein products of a primary early gene (ElA) (Berk et al. 1979; Jones and Shenk 1979; for review, see Nevins 1987) are all contributions from studies of this virus.

Another intriguing problem in gene regulation offered by adenovirus is the transcriptional unit encoding polypeptide IX, an adenovirus capsid protein (Pettersson and Mathews 1977). The IX gene, contained entirely within and $3^{\prime}$ coterminal with the E1B gene, is not transcribed early (Wilson et al. 1979; Crossland and Raskas 1983). In contrast, the E1B gene is active early in adenovirus infection. We were particularly attracted to the problem of how the IX gene, nested in a region of adenovirus DNA that is transcriptionally active early, is itself not active. Previous conjecture has been that either IX mRNA expression is repressed, perhaps by a capsid protein, prior to DNA replication or requires a late gene function for expression. Evidence for IX activation by late viral proteins has been sought by coinfection with a second virus of already infected cells. No evidence of early activation of protein IX by the superinfecting virus was observed
(Crossland and Raskas 1983). Such experiments suggested that if an activator for IX gene transcription existed, its action could not be separated from the requirement for DNA replication. Other studies (Matsui et al. 1986; Venkatesh and Chinnadurai 1987/ have suggested that merely the act of DNA replication was sufficient for IX mRNA production.

In this paper transient expression experiments were performed using plasmid DNAs containing a variety of DNA segments containing the IX gene. We found that replication alone, mediated by the SV40 origin, does not stimulate IX mRNA synthesis. We did find, however, that activation of IX gene expression from plasmids can occur, in the absence of DNA replication, if an E1B product is supplied in trans and there is little or no transcription across the IX promoter. Our results further show that early in adenovirus infection, E1B transcription across the IX gene is inhibitory to ElB-mediated activation.

\section{Results}

\section{Polypeptide IX mRNA synthesis in transfected cells}

A diagram of the E1B and IX transcripts and the proteins encoded by them is shown in Figure 1 (Bos et al. 1981; Green et al. 1982; Lewis and Anderson 1987). The E1B primary transcript is spliced differentially to yield at least four different mRNAs (Montell et al. 1984; Virtanen and Pettersson 1985), but IX mRNA is not spliced (Alestrom et al. 1980). The IX gene is nested within the 


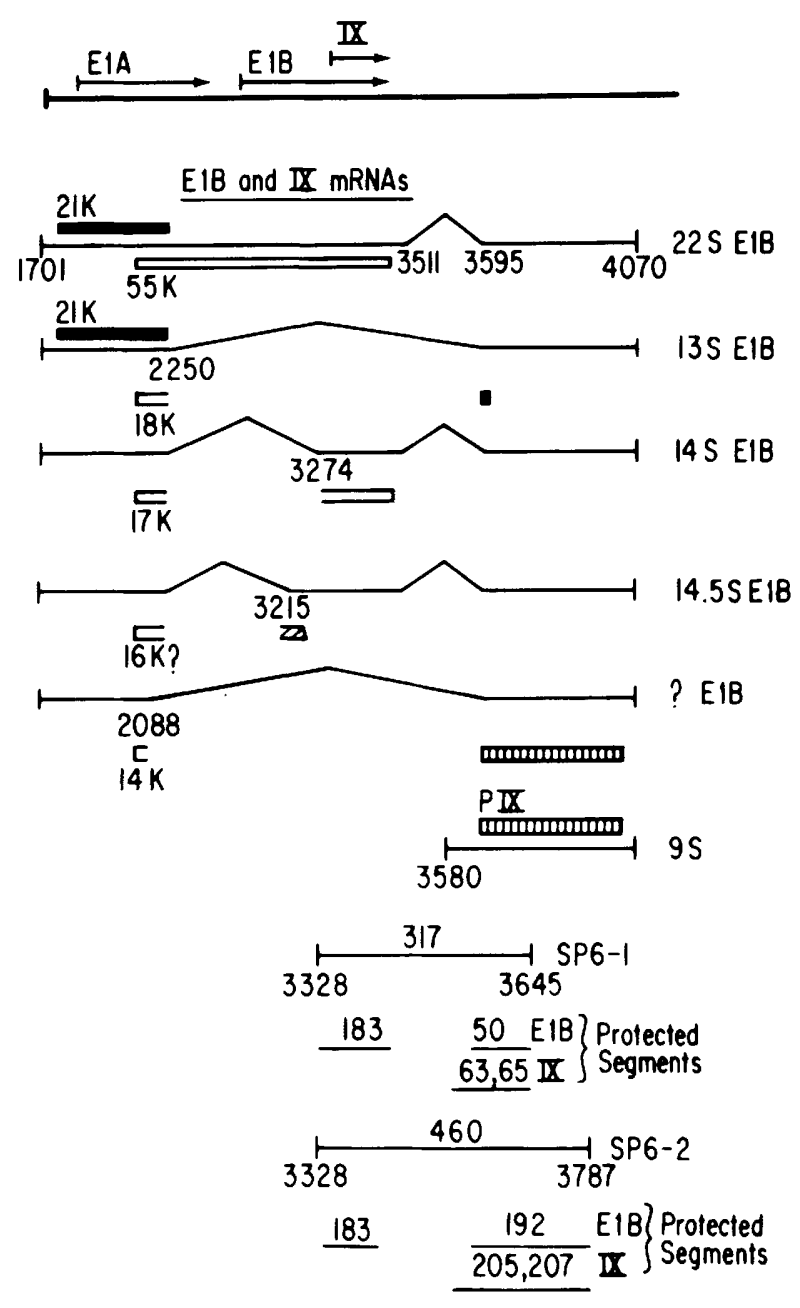

Figure 1. Diagram of the left end of the Ad5 genome with E1B and IX mRNAs and protein coding regions. E1B spliced mRNAs and encoded proteins identified to date are shown. All known ElB spliced mRNAs utilize the acceptor splice site at 3595 nucleotides. IX mRNA utilizes cap sites at 3580 and 3582 nucleotides. SP6-1 and SP6-2 antisense RNA probes spanning the IX cap site are shown along with the sizes of the protected fragments expected for E1B and IX mRNAs. Nucleotide positions are given on the adenovirus genome and are numbered from the left end of the viral genome.

ElB transcriptional unit and the same poly(A) addition site (located at nucleotide 4070 on the adenovirus genomel is used for both primary transcripts. The cap sites for IX mRNA (located at nucleotides 3580 and 3582 on the adenovirus genome) are 15 and $13 \mathrm{bp}$, respectively, upstream of the $3^{\prime}$ splicing site (3595 nucleotides) used in the formation of all E1B mRNAs. This 15-bp difference is used to identify and distinguish ElB and IX mRNAs isolated from infected or transfected cells using labeled antisense SP6 probes that span the IX promoter region (see Fig. 1). Figure 2B and Figure 3B (below) show the RNase T2-protected fragments that result when
mRNAs from early $(6 \mathrm{hr})$ and late $(15 \mathrm{hr})$ infected cells were hybridized to SP6-1 and SP6-2, respectively. With either antisense probe, the use of the E1B $5^{\prime}$ and $3^{\prime}$ splice sites surrounding the IX promoter are evident. In addition, it is clear that IX mRNA is detected only at late times after DNA replication has occurred.

To investigate the stringent requirement for DNA replication of IX gene expression, we designed experiments to determine if this gene is repressed early, activated late, or both. The first possibility we explored was that the adenovirus capsid contained a repressor protein that inhibited IX mRNA expression early during infection. The infectious adenovirus DNA-protein complex (ADPC) that retains only the covalently attached terminal protein (Sharp et al. 1976) was transfected into HeLa cells, and IX mRNA was assayed as a function of transfection time. Protein IX mRNA was not observed early ( $9 \mathrm{hr}$ ), but was observed after $16 \mathrm{hr}$ when DNA replication had occurred. If transfected cells were treated with cytosine arabinoside (Ara-C) to inhibit DNA replication, no IX mRNA was formed (data not shown, see Fig. 6B, below). Thus, no evidence was found that a repressor protein for the IX gene resided in the capsid.

We next examined a series of plasmids containing various segments of the ElA and ElB region to determine whether the simple removal of the IX transcription unit from the E1B transcription unit would allow activation of IX mRNA synthesis in HeLa cells (Fig. 2A). Two plasmids were used, one containing the EIA, E1B, and IX genes (1-5780 Ad5 nucleotides) and one containing only the IX gene $(3328-5780$ Ad5 nucleotides maintaining 250 nucleotides upstream of the IX start site). Both ElA (data not shown) and E1B mRNAs (see below) were observed using the 1-5780 nucleotide plasmid, but neither this plasmid nor the plasmid containing only the IX gene (see below) produced IX mRNA. In addition, cells containing these plasmids were also infected with the adenovirus mutant, d1313, which has a deletion of the E1B and IX genes, to see if proteins encoded by adenovirus could activate the IX gene on either of these vectors. IX mRNA synthesis was not stimulated, suggesting there was no virus function, with the possible exception of E1B, that activates the IX gene (data not shown).

To examine DNA replication as a means of activating IX gene expression, the SV40 origin of replication was inserted into the two plasmids containing the IX gene (Fig. 2A). The SV40 core ori was chosen to eliminate SV40 enhancer activity and COS-7 cells were used to support SV40 ori-mediated DNA replication (Gluzman 1981). The plasmid with 1-5780 nucleotides without (Fig. 2B, lane 3) and with (lanes 4 and 5) the SV40 ori in two orientations produced E1B mRNA, but not IX mRNA. Similarly, the plasmid with $3328-5780$ nucleotides without (lane 6) and with (lanes 7 and 8) the SV40 ori in two orientations did not produce IX mRNA. Replication of the transfected rlasmid DNA occurred (as tested by resistance of the replicated plasmid DNA to digestion by the restriction endonuclease $D p n I$, which does not cleave methylated DNA; data not shown). We detected RNA transcribed across the IX gene and spliced at the common E1B splice sites with the constructs con- 

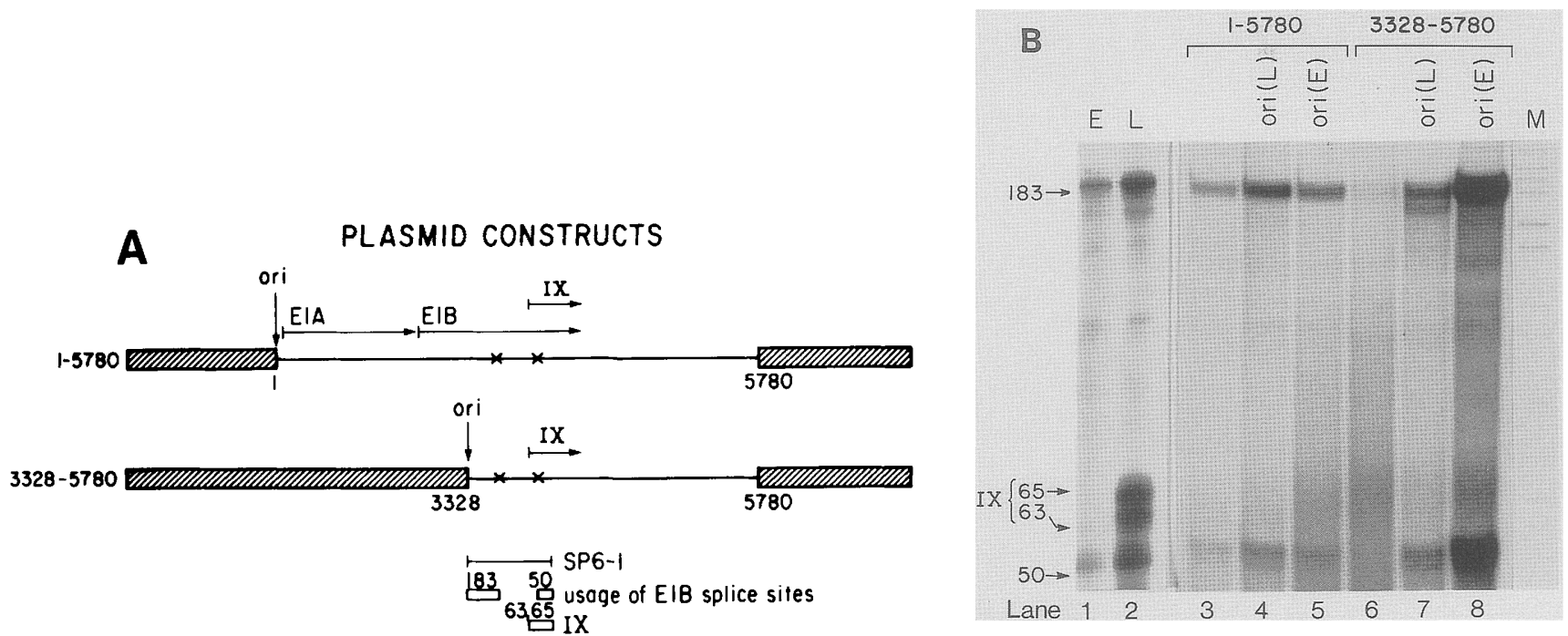

Figure 2. Failure of IX mRNA production from various replicating and nonreplicating plasmids. $(A)$ Plasmid constructs containing segments of the left end portion of adenovirus DNA are shown. The end points of adenovirus DNA are given in nucleotides and the hatched lines designate vector DNA. Arrows indicate the direction of transcription for E1A, E1B, and IX genes and the $x$ designates the position of E1B splice sites. The position at which the SV40 core ori was placed in these constructs is also indicated. Antisense SP6-1 RNA is shown, as well as the protected fragments predicted for RNA usage of the splice donor site at 3511 nucleotides (183 nucleotides) and of the splice acceptor site at 3595 nucleotides (50 nucleotides). IX mRNA is predicted to protect a doublet of 63 and 65 nucleotides. $(B)$ Denaturing polyacrylamide gel analysis of T2-resistant products obtained after hybridization of SP6-1 with cytoplasmic poly(A) containing RNA isolated from HeLa cells infected with Ad2 for $6 \mathrm{hr}$ (lane 1) or 15 hr (lane 2). The remaining lanes show a similar analysis of RNA from COS-7 cells transfected with 1-5780 nucleotides without (lane 3) and with (lanes 4 and 5) the SV40 ori in either orientation and 3328-5780 nucleotides without (lane 6) and with (lanes 7 and 8) the SV40 core ori in either orientation. A minor SV40 late promoter (lane 7) and the SV40 early promoter (lane 8) appear to direct transcription across the IX gene, as evidenced by usage of the E1B donor and acceptor splice sites at 3511 and 3595 nucleotides, respectively. (Lane $M$ ) Radiolabeled Hpall-digested pBR322 DNA as markers.

taining $3328-5780$ nucleotides, as indicated by protection of the 183- and 50-nucleotide bands. Thus, RNA probably is transcribed by a minor SV40 late promoter (lane 7) and the SV40 early promoter (lane 8) depending upon the orientation of the inserted SV40 ori. None of the constructs produced correctly initiated IX mRNA, however. We conclude that simple replication is insufficient to stimulate IX mRNA production.

\section{Activation of the IX gene when placed opposite in orientation to $E 1 B$}

At this point, no repressor effects on the protein IX gene were evident, simple replication did not activate the IX promoter, and no viral proteins, with the possible exception of an ElB protein, could activate the IX gene. To test whether the position of the IX transcriptional unit within the adenovirus genome would affect its activity, a plasmid was designed to remove the IX transcription unit from the E1B region and reinsert it in both orientations downstream from E1B (see Materials and methods). Figure 3A shows a diagram of these constructs. The construct $d l 30$ contains a deletion of the IX promoter leaving most of the E1B 3' exon. The IX gene (3328-5778 Ad2 nucleotides) was inserted within the E1B poly(A) site at 4057 nucleotides of $d 130$ in either orientation. These constructs, containing the newly positioned IX gene were designated $d 130$ ins IX and $d l 30$ ins IX opp to indicate the orientation of the inserted IX gene and were intended initially to be used in the construc- tion of adenovirus recombinants. First, however, we examined HeLa clone 2 cells transfected with these plasmids for any possible IX mRNA production. The SP6-2 probe containing sequences downstream from the deletion end point in $d 130$ was used to score E1B and IX mRNAs (see Fig. 3A,B). Transfection of cells with dl30, which lacks the IX promoter, gave rise to a protected fragment of 147 nucleotides (protecting 3640-3787 nucleotides of SP6-2) that presumably represented RNA initiated at the ElB cap site and transcribed across the remaining E1B region (Fig. 4A, lane 1). Transfection of cells with the two plasmids containing IX transcription unit insertions were also tested, producing an originally surprising but encouraging result (Fig. $3 \mathrm{C}$ ). The plasmid dl30 ins IX opp definitely produced substantial amounts of mRNA starting at the IX cap site. In contrast, very little IX mRNA was produced from plasmid containing the inserted IX gene downstream, but in the normal orientation (dl30 ins IX). The transfection of both these DNAs was approximately equal, as indicated by the similar amounts of the 147-nucleotide fragment, in both cases, that is derived from E1B transcription. The ratio of IX mRNA to this 147-nucleotide band in Figure 3C showed 12 times more IX mRNA from dl30 ins IX opp than from $d 130$ ins IX. In addition to the truncated ElB band (147 nucleotides) expected of $d 130$ constructs, the RNA sample from cells transfected with dl30 ins IX also protected bands of 192 and 183 nucleotides, indicating that E1B transcription across the IX promoter occurred 


\section{PLASMID CONSTRUCTS}

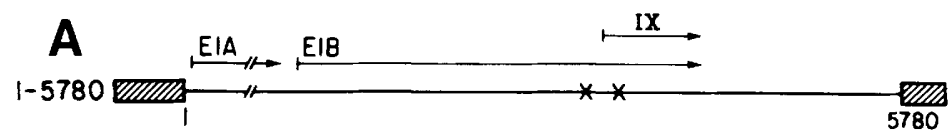

Figure 3. Activation of the IX gene on $d 130$ ins IX opp. (A) The plasmid construct dl30 containing a deletion of the IX promoter region and derivatives of $d l 30$ (d)l30 ins IX and $d 130$ ins IX opp) containing the IX gene (within a region containing Ad2 3323-5778 nucleotides/ inserted at the BclI site (4057 Ad2 nucleotides) are shown. Gaps in the DNA encompass the extent of the deletion. Plasmid 1-5780 nucleotides is also shown as a reference. Arrows indicate the direction of IX mRNA transcription; the $\mathrm{x}$ designates E1B splice sites, and opp refers to IX mRNA transcription being opposite to that of E1B. ElB mRNA is expected to utilize the same poly $(A)$ addition site as IX mRNA following ElB transcription across the IX promoter in dl30 ins IX; E1B mRNA is expected to utilize the IVA2 poly $(A)$ addition site at the end of the IX gene, without traversing the IX promoter region, in dl30 ins IX opp. SP6-2 antisense RNA is shown, as well as the predicted fragments that derive from RNA usage of the EIB splice sites at 3511 and 3595 nucleotides. Ad5-derived IX mRNA is expected to protect a region of 205 and $207 \mathrm{nu}$ cleotides. $(B)$ Analysis of RNA isolated from early $(6 \mathrm{hr}$, lane $E)$ and late $(15 \mathrm{hr}$, lane $L)$ adenovirus-infected HeLa cells using SP6-2 as probe. (Lane $M$ ) Markers. $(C \mid$ Analysis of RNA isolated from HeLa clone 2 cells transfected with dl30 ins IX and $d 130$ ins IX opp using the SP6-2 probe derived from Ad2 DNA (Lane $M$ ) Markers.
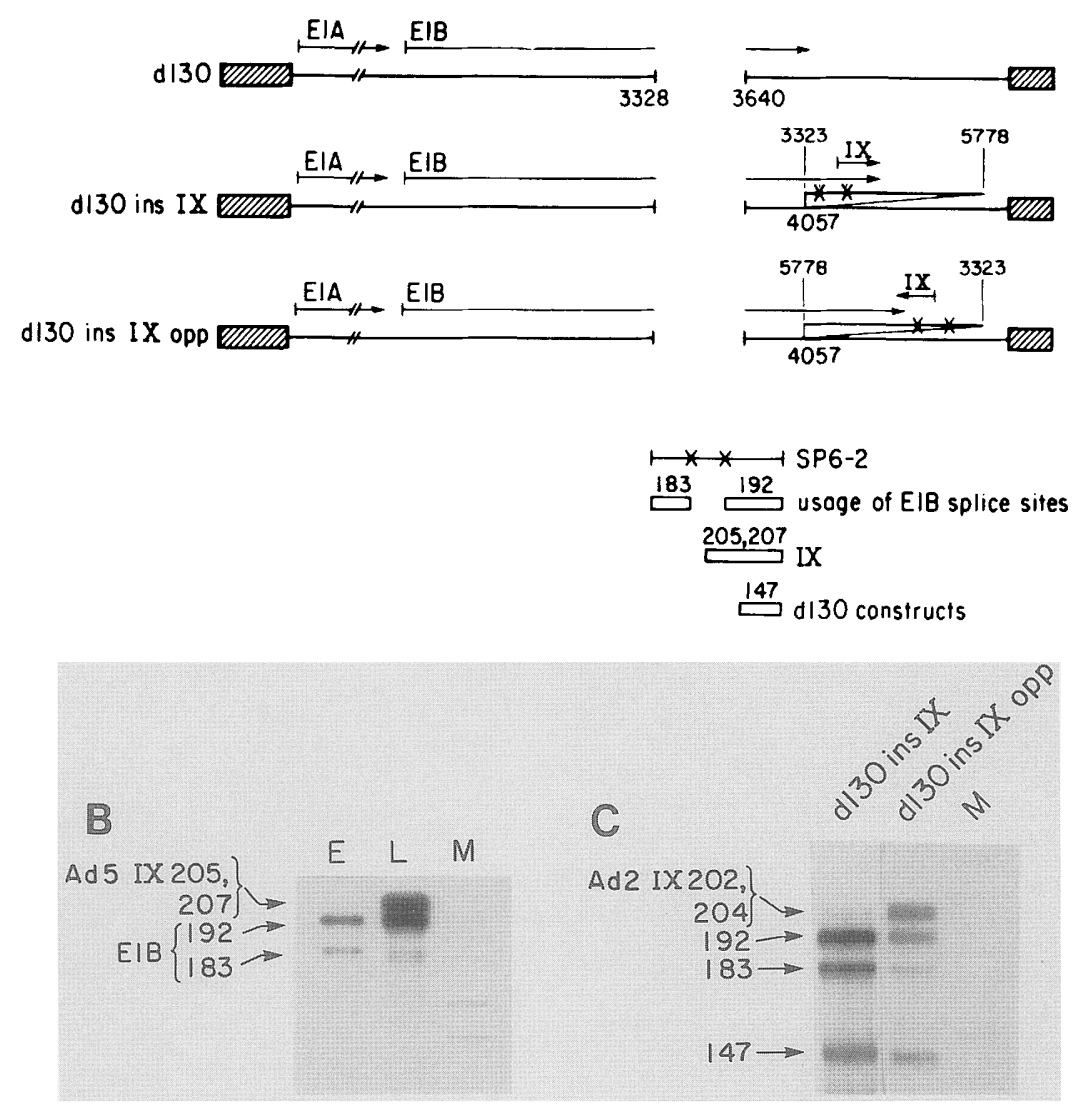

followed by usage of the splicing sites surrounding the IX promoter; in this case, ElB mRNA probably utilizes the same poly(A) addition site as IX mRNA. Weak bands of 192 and 183 nucleotides were also observed in the RNA from cells transfected with dl30 ins IX opp. These two bands indicated that a start site upstream of the IX gene and within the PMK2004 vector DNA probably occurred. Such a plasmid start site has been reported by others (Fuhrman et al. 1981). E1B mRNA probably utilizes the IVa2 poly(A) addition site located at the $3^{\prime}$ end of the inserted IX gene, without ElB transcription traversing the IX promoter in dl30 ins IX opp.

The finding that $d 130$ ins IX opp produced substantial amounts of IX mRNA suggested that two events may control IX gene expression: (1) E1A and/or E1B proteins encoded by the dl30 portion of this construct may activate IX mRNA synthesis and (2) E1B transcription across the IX promoter inhibits activation. We assume that the effects we have detected operate at the transcriptional level, since without activation no IX mRNA transcription occurs early in the infection; that is, IX regulation occurs at the transcriptional and not the post-transcriptional level. The remaining experiments in this paper explore the two possibilities mentioned above and show that both have a role to play in activation of the IX transcription unit.

dl30 activates the IX gene in trans and E1A proteins are not involved

Since the $d I 30$ ins IX opp plasmid produced IX mRNA, we tested whether the dl30 plasmid could stimulate, in trans, the production of IX mRNA from plasmids containing only the IX gene. Cotransfections were performed in HeLa S3 cells using two plasmids, the dl30 construct plus either of two plasmids containing only the IX gene, $(1)$ one containing adenovirus type $2(\operatorname{Ad} 2)$ DNA from 3323-5778 nucleotides or (2) one containing adenovirus type 5 (Ad5) DNA from 3328-5780 nucleotides. Constructs containing the IX gene alone were incapable of producing IX mRNA (Fig. 4A, lanes 3 and 4). In contrast, cotransfection of the dl30 plasmid led to substantial amounts of IX mRNA synthesis (lanes 5 and 6). Some product of the dl30 plasmid, therefore, activated the IX gene on a separate vector. We also noticed in this experiment that transcription across the IX gene in $d 130$ ins IX opp, presumably from a promoter in the vector DNA, was less pronounced in HeLa S3 cells than 

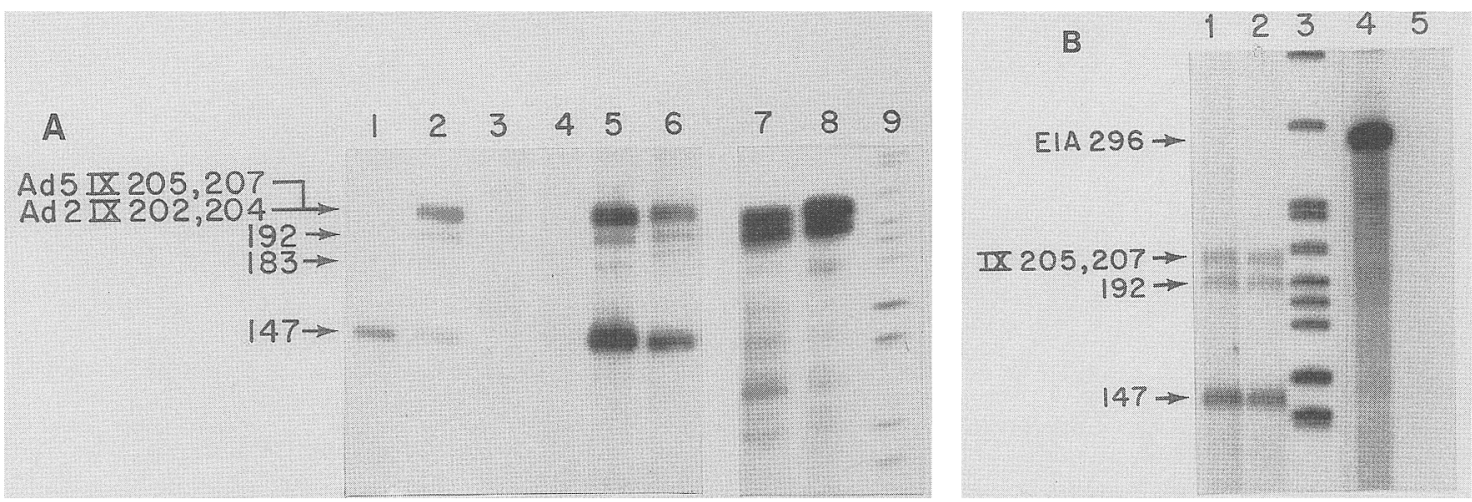

Figure 4. Activation of the IX gene by $d 130$ or $d 130 \mathrm{E}^{-} \mathrm{A}^{-}$in trans. (A) Analysis of RNA isolated from HeLa S3 cells transfected with the following plasmids: $d 130$ (lane 1), dl30 ins IX opp (lane 2), 3328-5780 Ad5 nucleotides alone (lane 3) and with dl30 (lane 5), 3323-5778 Ad2 nucleotides alone (lane 4) and with d130 (lane 6). (Lanes 7 and 8) Late infected Ad2 or Ad5 RNA, respectively, as markers. Two different SP6-2 probes derived from Ad2 or Ad5 DNA were used depending upon the type of DNA contained within the plasmids. Ad5 DNA contains an additional 3 bp at nucleotide 3596, close to the E1B acceptor splice site, so that T2 RNase digestion of hybrid molecules formed between IX mRNA (Ad2) and SP6-2 (Ad5) does not result in full-length Ad2 IX mRNA. Similarly, full-length protected fragments from Ad2 IX mRNA are 3 bp shorter than those from Ad5 IX mRNA (compare lanes 5 and 7 with lanes 6 and 8 ). (Lane 9) Markers. $(B)$ RNA from HeLa clone 2 cells cotransfected with the following plasmids: $3328-5780$ nucleotides and dl30 (lanes 1 and 4) or dl30 E1 A- (lanes 2 and 5) probed with SP6-2 (lanes 1 and 2) and SP6 antisense RNA for analysis of E1A mRNA (lanes 4 and 5; see Materials and methods). ElA mRNA protects a fragment of 296 nucleotides.

in HeLa clone 2 cells (cf. Fig. 3C and Fig. 4A, lane 2, which show dl30 ins IX opp in HeLa clone 2 and HeLa S3 cells, respectively). The amount of IX mRNA obtained from $d 130$ ins IX opp in these two cell lines, relative to the intensity of the 147-nucleotide band, was related inversely to the amount of plasmid-directed transcription across the IX promoter (see below). The next set of experiments was performed to determine more directly whether E1A or ElB proteins, both of which are encoded by $d 130$, were responsible for IX gene activation.

Since the $d 130$ plasmid encoded ElA mRNA and a deleted E1B mRNA, we tested whether the E1A region was necessary for activation of the IX gene. A derivative of dl30 was prepared leaving only 362 nucleotides upstream of the ElB promoter, i.e., deleting almost the entire ElA gene. This construct, $d 130 \mathrm{ElA}^{-}$, was cotransfected with the plasmid containing only the IX transcriptional unit (3328-5780 nucleotides). While E1A mRNA was not observed (Fig. 4B, lane 5), E1B mRNA was apparent (lane 2). We and others (Yoshida et al. 1987) have found that production of E1B mRNA in transient expression assays is not dependent upon ElA (lanes 1 and 2). Thus, we could examine the effect of E1B on IX mRNA formation in the absence of E1A. A clear production of IX mRNA was obtained (lane 2), eliminating E1A protein(s) as the activating agent. Transcription, initiated in vector sequences, that crossed the IX transcription unit was also activated in HeLa clone 2 cells (see Fig. 4B, 192-nucleotide band), and this phenomenon correlated with the lower activation of the IX gene in these cells compared with that observed in HeLa S3 cells (see below).

\section{The 21-kD E1B protein activates IX transcription}

The results presented in the previous section indicated that the $d 130 \mathrm{ElA}^{-}$plasmid activated the IX gene and, therefore, suggested that some E1B product was involved in stimulating IX mRNA formation. The ElB mRNA of dl30 $\mathrm{E}^{-\mathrm{A}^{-}}$was examined using various SP6 probes spanning the ElB region; no splicing events were evident (data not shown). Transfection with the plasmid dl30 $\mathrm{E}^{-} \mathrm{A}^{-}$, therefore, should produce two protein products, either of which is a candidate as trans-activator of the IX gene; the $21-\mathrm{kD}$ E1B protein and the $55-\mathrm{kD}$ E1B protein truncated at the carboxyl terminus. Figure 5 shows two constructs derived from $d 130 \mathrm{E} 1 \mathrm{~A}^{-}$ to test which E1B protein was involved. The plasmid dl30 $\mathrm{E} \mathrm{A}^{-} / \mathrm{P}$ is predicted to encode the $21-\mathrm{kD}$ E1B protein and a more truncated $55-\mathrm{kD}$ E1B protein. This plasmid also trans-activated the IX gene (Fig. 5, lane 3). A frameshift mutation was then placed within the plasmid $d 130 \mathrm{ElA}-/ \mathrm{P}$ in the coding region of the $21-\mathrm{kD}$ E1B protein, at 1774 nucleotides of the Ad5 sequence. The resulting plasmid, $d 130 \mathrm{E} 1 \mathrm{~A}^{-} / \mathrm{P} / \mathrm{S}^{*}$, did not transactivate the IX gene (lane 4). E1B mRNA was clearly detected from all constructs derived from $d 130 \mathrm{E}^{-\mathrm{A}^{-}}$(lanes 6-8). Since this frameshift mutation would not allow production of the $21-\mathrm{kD}$ ElB protein, we infer this protein is involved in IX gene activation.

\section{The 21-kD E1B protein did not activate the IX gene} promoter when transcription across IX occurred

Thus far, we have described activation of IX mRNA formation from d130 ins IX opp and from plasmids containing the IX transcription unit (Ad2 or Ad5) when they are cotransfected with the $d 130$ construct. In contrast, plasmids carrying 1-5780 nucleotides could not be stimulated by dl30 to form IX mRNA (Fig. 6A, lanes 1 and 2). In addition, cotransfection of $d l 30$ and the ADPC 
Figure 5. IX gene activation involves the 21-kD E1A protein encoded by $d 130 \mathrm{E}^{-} \mathrm{A}^{-}$. The bottom of the figure shows a schematic representation of $d 130 \mathrm{E}^{-1 \mathrm{~A}^{-} /}$ $\mathrm{P}$ and $d l 30 \mathrm{E} 1 \mathrm{~A}^{-} / \mathrm{P} / \mathrm{S}^{*}$, as well as the proteins predicted to be encoded by the E1B region in these plasmids. The star designates a frameshift mutation at 1774 Ad5 nucleotides in $d 130 \mathrm{E} 1 \mathrm{~A}^{-} / \mathrm{P} / \mathrm{S}^{*}$. The top of the figure shows an analysis of aliquots of RNA isolated from HeLa clone 2 cells transfected with 3328-5780 Ad5 nucleotides alone (lanes 1 and 5), or with dl30 ElA(lanes 2 and 6), dl30 ElA-/P (lanes 3 and 7), and dl30 E1A $-/ \mathrm{P} / \mathrm{S}^{*}$ (lanes 4 and 8 ) using SP6-2 (lanes 1-4) or SP6-NcoI (lanes 5-8, see Materials and methods). (Lane M) Markers.

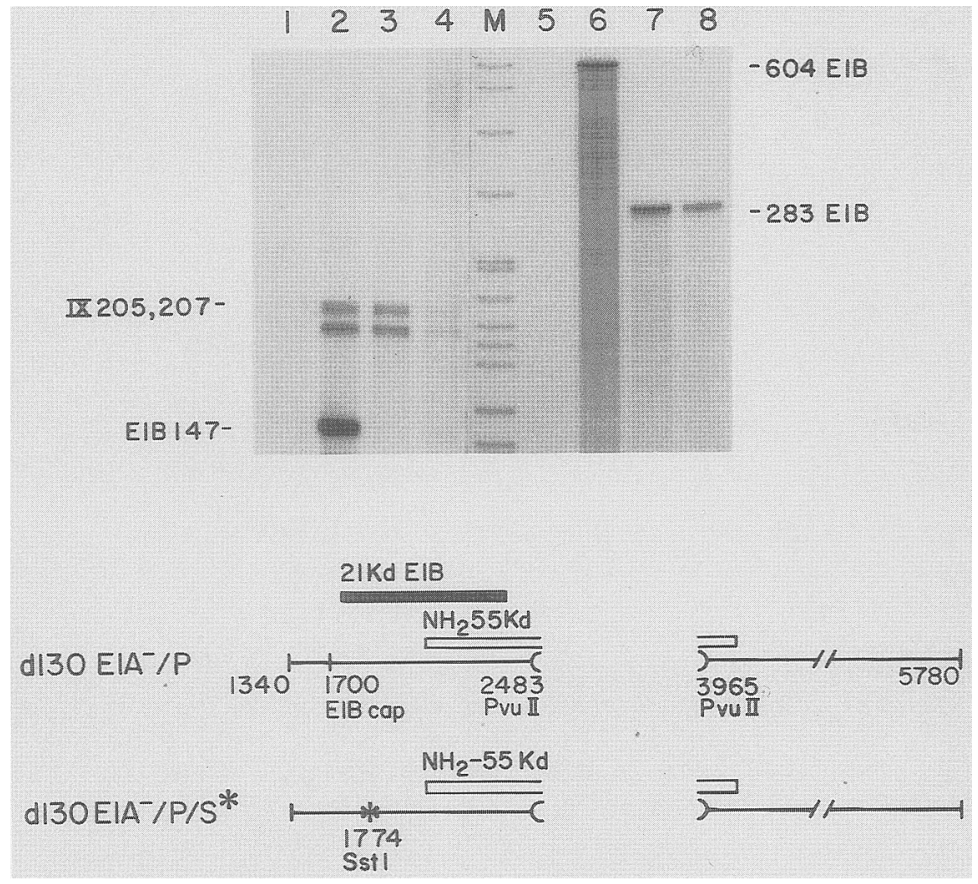

did not result in IX mRNA synthesis from the ADPC in the presence of Ara-C (Fig. 6B, lanes 2 and 3). The obvious difference between the ADPC or the 1- to 5780nucleotide plasmid, which could not be stimulated to produce IX mRNA, and the 3328- to 5780-nucleotide plasmid, which could, was the presence of E1A and E1B transcription initiation sites upstream of the IX promoter. These appeared to inhibit activation of the IX gene by $d l 30$. The possibility that the ElA gene contained within 1-5780 nucleotides may repress the IX gene was tested by removing the first 1338 nucleotides from the plasmid carrying 1-5780 nucleotides. The resulting plasmid produced E1B mRNA but did not produce IX mRNA upon transfection of HeLa cells, nor was it able to respond to cotransfection with $d 130$ (data not shown). The only adenovirus promoter remaining on the 1338- to 5780-nucleotide plasmid, therefore, other than that of the IX gene itself, was the ElB promoter. These results suggested that the nested position of the IX gene may inhibit its activation.

The possibility that active transcription across the IX promoter affects IX expression was tested directly. The E3 promoter is active in HeLa cells, even if transfected in the absence of E1A protein. When the protein IX transcription unit was inserted in either orientation within the E3 transcription unit, E3 ins IX and E3 ins IX opp, the protein IX promoter in both constructs was inactive (Fig. 6C, lanes 1 and 3). E3 transcription across the IX gene clearly was evident from the transfected plasmid E3 ins IX in which the distal E1B donor and acceptor splice sites, contained within the IX insert, were used (lane 1). While cotransfection experiments using d130 $\mathrm{ElA}^{-}$did not activate IX mRNA synthesis from E3 ins IX (lane 2), the IX gene contained within E3 ins IX opp
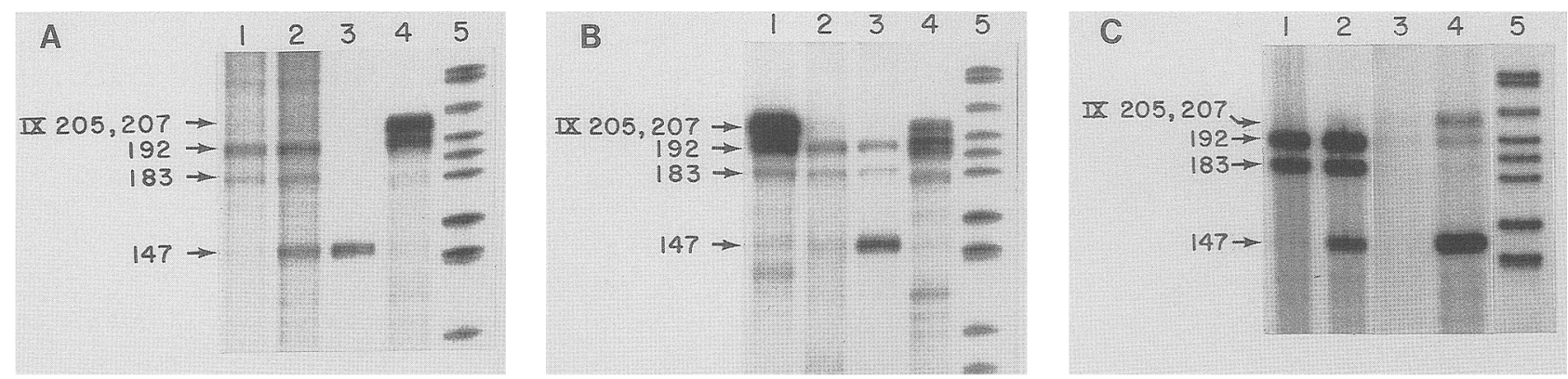

Figure 6. Promoters upstream of and overlapping the IX gene inhibit dl30 activation. (A) SP6-2 analysis of HeLa clone 2 transfected with 1-5780 nucleotides alone (lane 1) and with dl30 ElA- (lane 2). (Lane 3) dl30 El A- alone; (lane 4) late infected HeLa cells; (lane 5) markers. (B) A similar analysis of cells transfected with ADPC for $16 \mathrm{hr}$ alone (lane 1), in the presence of Ara-C (lanes 2 and 3 ), and dl30 (lane 3). (Lane 4) Late infected HeLa cells; (lane 5) markers. (C) A similar analysis using E3 ins IX or E3 ins IX opp alone (lanes 1 and 3 , respectively) or with $d 130 \mathrm{E} 1 \mathrm{~A}^{-}$(lanes 2 and 4 , respectively); (lane 5 ) markers. 
was activated (lane 4). This result is in accord with the original experiment using dl30 ins IX in which the IX transcriptional unit in the same orientation as E1B was much less active in producing IX mRNA than dl30 ins IX opp, pointing to a suppression of IX activation by an upstream promoter. These experiments with plasmids produced a coherent picture that the $21-\mathrm{kD}$ ElB protein formed from $d 130$ activated the IX gene when little or no transcription across the IX promoter occurred. The IX gene normally resides in the linear adenovirus chromosome, and we wanted to test these conclusions from the plasmid experiments in a virus genome.

\section{Virus infections confirm transfection results}

The Ad5 virus construct AdBgl6 (Friedman et al. 1986) is analogous to plasmid constructs, described in the previous sections, in which the ElA gene and ElB promoters upstream of the IX gene have been removed. The AdBgl6 virus has a deletion of 195-3328 nucleotides, leaving the IX promoter region intact. By itself, this virus did not produce IX mRNA during $17 \mathrm{hr}$ of infection in HeLa cells (Fig. 7, lane 1). The overall infection process is predicted to be delayed with this defective virus since ElA proteins are absent. Weak transcription across the IX gene, evidenced by splicing at E1B sites, apparently initiates within the first 194 nucleotides (Hearing and Shenk 1983). Our transfection results predicted that in the absence of E1B transcription across the IX gene, IX mRNA would be synthesized without DNA replication, if the $21-\mathrm{kD}$ E1B protein was also present during the infection. A coinfection employing the AdBgl6 virus with

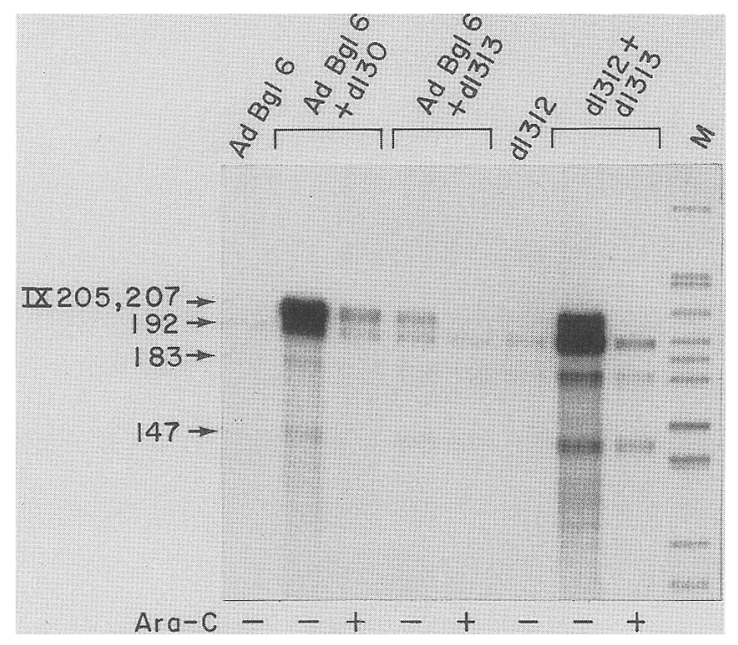

Figure 7. IX mRNA synthesis in the absence of DNA replication using a virus construct lacking E1A and E1B promoters upstream of IX. SP6-2 (Ad5) analysis of RNA isolated from HeLa clone 2 cells infected for $17 \mathrm{hr}$ in the absence or presence of Ara-C as indicated. The viruses used are indicated at the top of the lanes. (Lane $M$ ) Markers. the virus derivative of $d l 30$ (L. Vales, L. Babiss, and J. Darnell, in prep.) therefore was performed in the absence (lane 2) and presence (lane 3) of Ara-C; IX mRNA indeed was observed in the absence of DNA replication. When a coinfection was performed, however, with AdBgl6 and the mutant $d 1313\left(\mathrm{E}_{1 \mathrm{~B}^{-}}, \mathrm{IX}^{-}\right)$, very little IX mRNA was observed from AdBgl 6 (lane 4) and IX mRNA was absent with Ara-C (lane 5), indicating the requirement for the 21-kD E1B protein furnished by the dl30 virus, but not by the dl313 virus. The E1A deletion mutant virus dl312, which leaves the E1B promoter intact and in its normal position upstream of the IX gene, was also examined to test again the suppressive effect on IX mRNA synthesis of the ElB promoter. IX mRNA was not observed from $d 1312$ alone (lane 6). When the E1A defect in dl312 was complemented by coinfection with dl313, E1B transcription across the IX promoter in dl312 occurred and no IX mRNA was detected in the presence of Ara-C (lane 8). The coinfection of $d 1312$ and $d 1313$ was only productive for IX mRNA when DNA replication occurred (lane 7). These results confirmed, therefore, that the IX gene in adenovirus is activated, without DNA replication, in the absence of upstream promoters and when the $21-\mathrm{kD}$ E1B protein from dl30 is provided.

We next tested wild-type virus for the stimulating E1B activity that is supplied by the dl30 virus. This experiment was performed with wild-type Ad2 and the AdBgl6 virus, which is an Ad5 derivative. The IX mRNAs of Ad2 and Ad5 can be scored separately using SP6-2 probes derived from Ad2 or Ad5 DNAs (Fig. 8, lanes 7 and 8). In the presence of Ara-C, IX mRNA from the wild-type virus (type 2) alone (lane 4) or coinfected with wild-type virus (type 5) (lanes 5 and 6) was not observed. However, a distinct IX mRNA signal of the type 5 variety, that is, from AdBgl6, was observed without DNA replication, during coinfection with Ad2 wild-type virus (lanes 2 and 3). Thus, the wild-type virus, without replication, encodes the E1B activity necessary to stimulate IX mRNA synthesis from the AdBgl6 genome, while the IX gene in the wild-type virus is itself silent.

Finally, the AdBgl6 virus was used to infect the adenovirus transformed cell line, 293 (Graham et al. 1977). This cell line contains the E1A, ElB, and IX genes and produces an abundant amount of E1A and E1B mRNAs, but no detectable IX mRNA. The pattern of mRNA production from the integrated viral DNA, therefore, resembles the early phase of an adenovirus infection (Spector et al. 1980). Without DNA replication, a definite IX signal was obtained from the AdBgl6 virus in these cells, confirming that an E1B product is involved in IX mRNA transcription (Fig. 9).

We noted that in the absence of Ara-C, higher levels of IX mRNA accumulated in coinfections of HeLa cells with AdBgl6 and dl30 compared to coinfections with d1312 and d1313 (Fig. 7, cf. lanes 2 and 7). Similarly, higher levels of IX mRNA compared to ElB mRNAs were obtained in 293 cells infected with AdBgl6 relative to the wild-type virus (Fig. 9, cf. lanes 3 and 4). We attribute this observation to IX gene repression in viruses containing E1B, which must be alleviated before IX mRNA can be formed. 
Figure 8. A wild-type activity from early infected cells activates IX gene expression from AdBgl6 virus without DNA replication. Analysis of RNA isolated from HeLa clone 2 cells infected for $17 \mathrm{hr}$ with the viruses indicated at the top of the lanes. Infections were performed in the absence or presence of Ara-C as indicated. SP6-2 probes derived from Ad2 or Ad5 DNAs were used to differentiate Ad2 and Ad5 IX mRNAs. Ad5 IX mRNA can be distinguished from Ad2 IX mRNA due to the fact that it contains 3 additional nucleotides internal to the gene /starting at 3596 Ad5 nucleotides). Therefore, SP6-2 probes that are synthesized from Ad2 DNA (SP6-2/2) will result in similar protected fragments of IX mRNA 1202, 204 nucleotides) from either Ad2 or Ad5 genes. However, SP6-2 probes synthesized from Ad5 DNA (SP6-2/5) will result in a full-length Ad5 IX mRNA hybrid $(205,207)$ or a truncated Ad2 IX hybrid $\{188$ nucleotides). In this way, Ad5 and Ad2 IX mRNAs can be scored separately. (Lanes 7 and 8) Different aliquots of Ad2 late infected RNA analyzed with SP6-2/5 and SP6-2/2, respectively. Full-length protected fragments of the appropriate size for IX

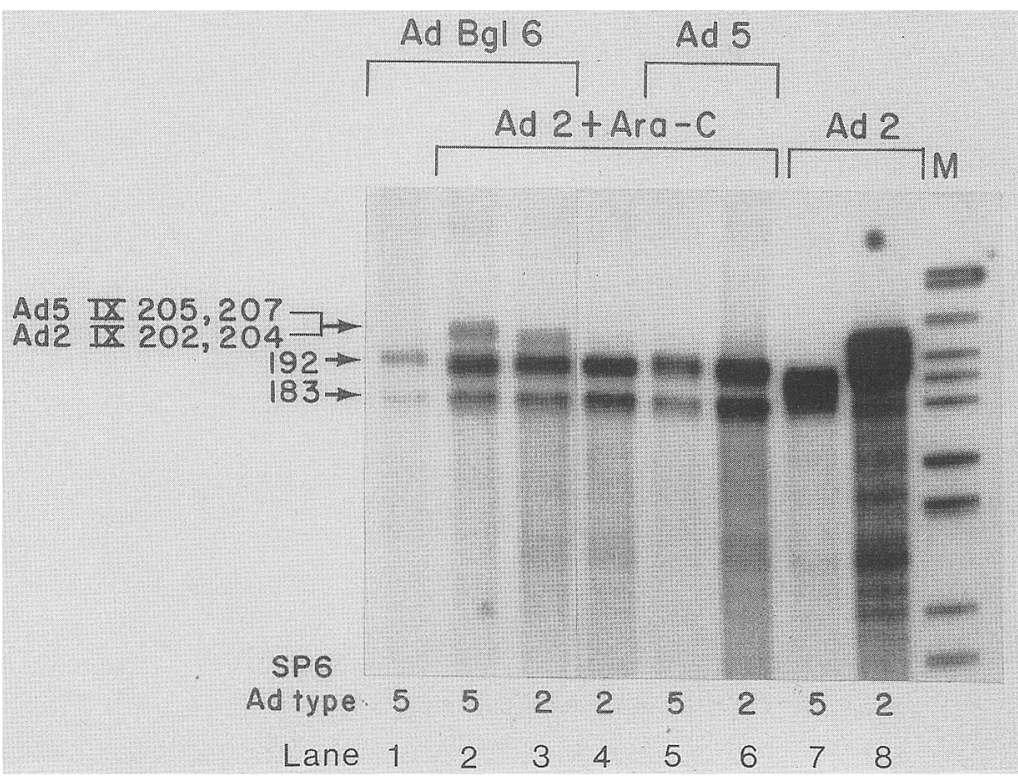
mRNA are detected only with SP6-2/2. (Lanes 2 and 3) Different aliquots of RNA isolated from a coinfection with AdBgl6 and wild-type Ad2 viruses performed in the presence of Ara-C. Full-length protected fragments for IX mRNA were observed using SP6-2/5 or SP6-2/2 probes; IX mRNA synthesized under these conditions, therefore, was derived only from Ad5 DNA, that is, AdBgl6 virus. (Lane 9) Markers.

\section{Discussion}

We began this research with knowledge that protein IX mRNA formation from wild-type virus required DNA replication. We found no evidence that capsid proteins are responsible for repression of IX mRNA formation or that simple replication of the IX transcription unit on a plasmid would suffice to allow IX transcription. The failure of DNA replication to activate IX transcription contrasted with two previously published reports (Matsui et al. 1986; Venkatesh and Chinnadurai 1987) and requires an explanation. Matsui et al. used plasmid constructs containing the IX gene in conjunction with the SV40 ori and SV40 enhancer; IX mRNA was observed. However, the contribution of the enhancer activity to the expression of the heterologous IX gene was not addressed. Our constructs did not contain the enhancer and no IX mRNA was produced. Therefore, the production of IX mRNA observed by Matsui et al. using the SV40 enhancer does not appear to be relevant to authentic IX gene expression. This same concern apparently led Venkatesh and Chinnadurai also to examine IX mRNA synthesis from plasmids containing the IX transcriptional unit and the SV40 ori without the corresponding enhancer. Their results, using 5 '-end labeled antisense DNA probes, showed protected fragments of 305 nucleotides that increased during replication of the plasmids. However, the size of this protected fragment corresponds to RNA transcribed across the inserted IX region and spliced at the E1B acceptor site downstream of the IX cap sites, rather than to properly initiated IX mRNA. Had the correct start sites for IX mRNA been used, bands of 315 and 317 nucleotides would be present. A barely detectable doublet that appeared to be approximately $12 \mathrm{bp}$ longer than the 305-nucleotide fragment was obtained with the ori constructs, and we believe that these protected fragments were IX mRNA. The authors explained these protected bands on the basis of heterogeneity in IX mRNA start sites. The documented heterogeneity, however is a 2-bp difference, not a 12-bp difference. Thus, in neither of the previous studies is there sufficient evidence that replication alone can stimulate IX mRNA synthesis.

In searching for a means to activate the IX gene, we removed it from the E1B transcription unit and reinserted it in reverse orientation into a plasmid construct containing the ElA and ElB transcription units, and, for the first time IX mRNA was produced from a recombinant construct in the absence of replication. Further analysis showed that the necessary elements for successful IX mRNA production appeared to be the $21-\mathrm{kD}$ E1B protein from a deleted form of the E1B transcription unit plus an orientation of the IX transcription unit opposite to the remaining ElB promoter. ElA gene products were not required. Furthermore, the activation by the E1B protein could come from a separate plasmid stimulating the IX transcription unit in trans. Not only plasmids but also virus experiments support these conclusions: The AdBgl6 virus that lacks promoters upstream of IX and cannot make either E1A or 1B proteins, could produce IX mRNA without DNA replication if the $21-\mathrm{kD}$ protein is furnished by $d 130$ or wild-type viruses.

The 21-kD E1B protein has already been shown to activate enhancer-driven promoters (Yoshida et al. 1987). Our analyses of the IX promoter (L. Vales, L. Babiss, and J. Darnell, in prep.) indicate no demonstrable enhancer site associated with IX gene expression. The 21-kD E1B protein, therefore, may act on the IX gene in a different manner. Herrmann et al. (1987) studied the ability of the 21-kD E1B protein to activate several adenovirus pro- 


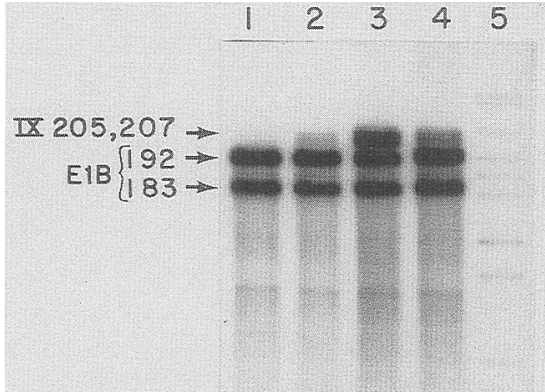

Figure 9. AdBgl6-infected 293 cells express IX mRNA without DNA replication. SP6-2 analysis of 293 cells alone (lane 1) and after infection for $12 \mathrm{hr}$ with AdBgl6 virus in the presence (lane 2) or absence (lane 3) of Ara-C. (Lane 4) Wild-type Ad5 infected 293 cells; (lane 5) markers.

moters by scoring for chloramphenicol acetyltransferase (CAT) activity. They concluded that the $21-\mathrm{kD}$ E1B protein activates all the adenovirus genes expressed early in infection, but not those genes expressed late in infection, including the IX gene. Our analyses of IX mRNA synthesis indicate that the $21-\mathrm{kD}$ ElB protein activates the IX gene. The CAT assays employed in the previous studies may not have been sensitive enough to detect increases in IX promoter usage or, alternatively, the IXCAT fusion mRNA may not have been stable.

From the experiments presented here, we propose the following pattern of events during the course of a normal adenovirus infection. The virion DNA enters the nucleus and engages the host transcriptional machinery. The products of the ElA genc, expressed early in infection, activate the ElB gene (Nevins et al. 1979). Our evidence indicates that the $21-\mathrm{kD}$ ElB protein, in turn, activates the IX gene. Transcription of the E1B gene is therefore necessary, and yet E1B transcription across the IX promoter inhibits IX activation by this E1B protein. We propose that, early in the adenovirus infection, all transcriptionally active templates are committed to E1B transcription, thereby silencing the IX gene. After DNA replication, however, this would no longer be true. This model does not propose an overall decrease in E1B transcription after DNA replication, but instead, a decrease in E1B transcription per template. Promoter occlusion has been identified as a transcriptional regulatory event in prokaryotes (Adhya and Gottesman 1982), and, in studies presented here, the activation of the IX gene by the $21-\mathrm{kD}$ E1B protein is inhibited by E1B transcription across the IX promoter. What might be the mechanism by which E1B transcription prevents IX mRNA transcription? First, protein factors that activate E1B might cause a propagated change within the entire E1B transcription unit so that the IX promoter cannot attach any factors. A second possibility is that RNA polymerase transit blocks attachment of necessary factors at the IX promoter, even though the proper factors, including the ElB protein, are present. Only after replication are templates free of activated E1B transcription units and then the already formed E1B product can activate the newly replicated genomes. Thus, the act of replication is not required except to produce clean templates, which in the presence of the proper activation factors, can become activated.

While to our knowledge, there are no proven cases of a eukaryotic gene that is repressed by overriding transcription or a gene that requires replication for activation (Brown 1984), we suspect that, as has happened repeatedly, the understanding of adenovirus gene expression may shed light on cellular processes. DNA replication is widely thought to be required for developmental gene activation and the explanation has often been offered that the newly replicated gene would have a chance to engage transcription factor(s) that did not exist in the cell the last time that gene was replicated. The results with the protein IX gene are certainly in accord with that possibility and add the additional possibility that a contiguous or similarly oriented gene has the ability to block downstream genes; thus, promoter occlusion must be alleviated to ensure activation of the downstream gene.

\section{Materials and methods}

Cells, virus stocks, and infections

HeLa clone 2 and S3 cells were obtained from the American Tissue Culture Company. Wild-type Ad5 and Ad2 were grown in HeLa monolayer cultures. Mutant viruses dl312, dl313 (Jones and Shenk 1979), AdBgl6 (Friedman et al. 1986), and dl30 (L. Vales, L. Babiss, and J. Darnell, in prep.) were grown on monolayers of the complementing 293 cell line (Graham et al. 1977). We are grateful to Lee E. Babiss for the gift of AdBgl6. ADPC was isolated from wild-type Ad5 virus grown in HeLa S3 suspension cultures by disrupting virions in an equal volume of $8 \mathrm{~m}$ guanidine $\mathrm{HCl}$ in $10 \mathrm{~mm}$ Tris $(\mathrm{pH} 7.9)$ and $1 \mathrm{~mm}$ EDTA and loading a Sepharose $4 \mathrm{~B}$ column equilibrated in $4 \mathrm{M}$ guanidine$\mathrm{HCl}, 10 \mathrm{~mm}$ Tris ( $\mathrm{pH} 7.9$ ), and $1 \mathrm{~mm}$ EDTA. All operations were performed at $4^{\circ} \mathrm{C}$, and $\mathrm{ADPC}$ was found in the excluded volume.

Nearly confluent HeLa clone 2 or 293 monolayer cells (150 $\mathrm{mm}$ plates) were infected at an moi of 20 for each virus used. Virus was adsorbed in $1 \mathrm{ml}$ of DME for $90 \mathrm{~min}$, at which time $30 \mathrm{ml}$ of DME containing $2 \%$ FCS was added. Cytosine arabinoside (Ara-C) was added at the time of adsorption and feeding, and at $6 \mathrm{hr}$ subsequently at a concentration of $50 \mu \mathrm{g} / \mu \mathrm{l}$.

\section{Plasmid constructions}

Plasmid 1-5780 nucleotides contains Ad5 DNA inserted into the BamHI and XhoI sites of PMK2004 DNA and was a gift from Lee E. Babiss. Plasmid 3328-5780 nucleotides was isolated after digestion of plasmid 1-5780 nucleotides with $B a m H I$ and BglII restriction enzymes and subsequent ligation. Plasmid 3323-5778 Ad2 nucleotides was isolated by exchanging the BamHI-XhoI fragment in PMK2004 with the BgIII-XhoI fragment isolated from plasmid 2800-6232 Ad2 nucleotides, which was a gift from Erik Falck-Pederson. PMK2004 (2x21) (Bergsma et al. 1982) was used to isolate the SV40 core ori contained within BamHI-linkered DNA. Plasmid 1-5780 nucleotides was digested with BamHI or BamHI and BgIII, and the fragments were then ligated to the SV 40 core ori. Plasmids $1-5780$ nucleotides and 3328-5780 nucleotides containing the core ori in either orientation were thereby obtained. dl30 was constructed using Bal31 digestion of BglII-cleaved plasmid 1-5780 nucleotides. BamHI linker ligation of the product and subsequent $X$ hol digestion yielded a fragment containing 3640 
(BamHI)-5780 (XhoI) Ad5 nucleotides. This fragment was used to replace the 3328 (BglII)-5780 (XhoI) nucleotides fragment in plasmid 1-5780 nucleotides. To make use of the Bcll site at 4057 Ad2 nucleotides, the SphI fragment of the deletion mutant was exchanged for the same fragment of Ad2 DNA contained within plasmid 2800-6232 nucleotides. The resulting product was $d 130$. Another fragment of plasmid 2800-6232 nucleotides was used to isolate the IX gene. In this case, $X h O I$-cleaved DNA was ligated to $B a m H I$ linkers and subsequently cleaved by BgIII, yielding a fragment containing 3323 (BgIII)-5778 (BamHI) Ad2 nucleotides. This fragment was inserted into the $B c I I$ site of $d l 30$ to derive $d l 30$ ins IX and $d 130$ ins IX opp. ElAconstructs were derived from 1-5780 nucleotides and $d 130$ by digestion of the BamHI and $\mathrm{XbaI}$ sites and subsequent ligation of these sites made blunt-ended by treatment with the Klenow fragment of DNA polymerase I. dl $30 \mathrm{E} 1 \mathrm{~A}^{-} / \mathrm{P}$ was derived from dI30 $\mathrm{ElA}^{-}$by removal of the Pvull fragment containing 2484-3964 Ad5 nucleotides. The products of SstI digestion of dl30 $\mathrm{E} 1 \mathrm{~A}^{-} / \mathrm{P}$ were made blunt-ended using $\mathrm{T} 4$ polymerase and then religated to construct $d 130 \mathrm{E} 1 \mathrm{~A}-/ \mathrm{P} / \mathrm{S}^{*}$. Plasmids containing the IX gene within and in the same orientation as the E3 gene, E3 ins IX, or the opposite orientation, E3 ins IX opp, were isolated as follows. The Ad5 fragment within 3328-5780 nucleotides was made blunt-ended, and $\mathrm{XbaI}$ linkers were ligated to the termini. This fragment containing the IX gene was used to replace the $X b a I$ fragment in 59-100 Ad5 units contained within pBR322 DNA. (gift from Paul Freimuth).

\section{Transfections}

HeLa clone 2, S3, and COS-7 monolayer cultures $150 \mathrm{~mm}$ plates) at $60-80 \%$ confluency were transfected using the calcium phosphate procedure (Wigler et al. 1979). Medium was replenished $6 \mathrm{hr}$ before addition of precipitate and a total of $60 \mu \mathrm{g}$ of DNA $130 \mu \mathrm{g}$ of each cotransfected plasmid, or $30 \mu \mathrm{g}$ of pGem-1 as carrier), were added directly to the medium. For ADPC, $15 \mu \mathrm{g}$ of DNA was used per plate with $30 \mu \mathrm{g}$ of carrier or dl30 DNA as indicated. After a 4-hr (ADPC) to overnight incubation, cells were glycerol-shocked in HEPES-buffered saline containing $15 \%$ glycerol. Cells were then harvested 16-24 hr later. When appropriate, cytosine arabinoside was added at 50 $\mu \mathrm{g} / \mathrm{ml}$ every $8 \mathrm{hr}$.

\section{RNA preparation}

Cells were harvested and lysed in 0.5\% NP-40 (Nevins 1980), and oligo(dT)-cellulose selection of cytoplasmic RNA was performed in all cases.

\section{RNase T2 analyses}

The Ad2 sequences between 2800 (HindIII) and 3642 (SstI) nucleotides were cloned into pSP65 and linearized with BglII for synthesis of SP6-1. The Ad2 sequences between 3323 (BgIII) and 3780 (PstI) nucleotides were cloned into pGem-2 and linearized with EcoRI for synthesis of SP6-2. The Ad5 version of SP6-2 has been described (Friedman et al. 1986). SP6 probe (1339-1774 Ad5 nucleotides/ for E1A mRNA analyses was derived from $X b a I$-linearized pSP65 DNA containing 310-1774 Ad5 nucleotides, a gift from R.P. Hart. SP6 probe (2205-2804 Ad5 nucleotides) for E1B mRNA analyses was derived from $\mathrm{NcoI}$-linearized pSP65 DNA containing 1774-2804 Ad5 nucleotides. Approximately $0.5-1 \mu \mathrm{g}$ of RNA was hybridized to appropriate SP6 probes labeled to $5 \times 10^{7} \mathrm{cpm} / \mu \mathrm{g}$ of DNA with [ $\left.{ }^{32} \mathrm{P}\right] \mathrm{GTP}$. The conditions of probe synthesis and hybridization to RNA samples at $62^{\circ} \mathrm{C}$ were as already described (Melton et al. 1984). T2 RNase was added at a concentration of $60 \mathrm{U} / \mathrm{ml}$ in $300-\mu l$ aliquots on ice (Hart et al. 1985). The reactions were performed at $31^{\circ} \mathrm{C}$ for $45 \mathrm{~min}$, terminated by the addition of $100 \mu \mathrm{l}$ of $4 \mathrm{M}$ ammonium acetate and $5 \mu \mathrm{g}$ of carrier yeast RNA, and RNA was ethanol-precipitated. The products of digestion were denatured and fractionated by electrophoresis in $8 \mathrm{M}$ urea- $6 \%$ polyacrylamide gels at $30 \mathrm{~mA}$ for $2 \mathrm{hr}$. Protected radiolabeled fragments were visualized by autoradiography.

\section{Acknowledgments}

We appreciate the many helpful discussions with Nancy Reich, Lee Babiss, Erik Falck-Pederson, and Danny Reinberg. We are especially grateful to Nancy Reich and Jovan Merkovitz for their critical reading of this manuscript and the improvements they suggested. We thank Sushma Patel for excellent technical assistance. This work was supported by grants from the $\mathrm{Na}$ tional Institutes of Health (CA 16006-14, CA 18213-12, and CA 28414) and the American Cancer Society (NP 624Q).

\section{References}

Adhya, S. and M. Gottesman. 1982. Promoter occlusion: Transcription through a promoter may inhibit its activity. Cell 29: 939-944.

Alestrom, P., G. Akusjarvi, M. Perricaudet, M.B. Mathews, D.F. Klessig, and U. Pettersson. 1980. The gene for polypeptide IX of adenovirus type 2 and its unspliced messenger RNA. Cell 19: 671-681.

Bergsma, D.J., D.M. Olive, S.W. Hartzell, and K.N. Subramanian. 1982. Territorial limits and functional anatomy of the simian virus 40 replication origin. Proc. Natl. Acad. Sci. 79: 381-385.

Berk, A.J., F. Lee, T. Harrison, J. Williams, and P.A. Sharp. 1979. Pre-early adenovirus 5 gene product regulates synthesis of early viral messenger RNAs. Cell 17: 935-944.

Bos, J.L., L.J. Polder, R. Bernards, P.I. Schrier, P.J. van den Elsen, A.J. van der Eb, and $\mathrm{H}$. van Ormondt. 1981. The $2.2 \mathrm{~kb}$ ElB mRNA of human Adl 2 and Ad5 codes for two tumor antigens starting at different AUG triplets. Cell 27: 121-131.

Brown, D.D. 1984. The role of stable complexes that repress and activate eukaryotic genes. Cell 37: 359-365.

Crossland, L.D. and H.J. Raskas. 1983. Identification of adenovirus genes that require template replication for expression. I. Virol. 46: 737-748.

Friedman, J.M., L.E. Babiss, D.F. Clayton, and J.E. Darnell, Jr. 1986. Cellular promoters incorporated into the adenovirus genome: Cell specificity of albumin and immunoglobulin expression. Mol. Cell. Biol. 6: $3791-3797$.

Fuhrman, S.A., C.V. Beveren, and I.M. Verma. 1981. Identification of a RNA polymerase II initiation site in the long terminal repeat of Moloney murine leukemia viral DNA. Proc. Natl. Acad. Sci. 78: 5411-5415.

Gluzman, Y. 1981. SV40-transformed simian cells support the replication of early SV40 mutants. Cell 23: 175-182.

Graham, F.L., J. Smiley, W.C. Russell, and R. Nairn. 1977. Characteristics of a human cell line transformed by DNA from human adenovirus type 5. I. Gen. Virol. 36: 59-72.

Green, M., K.H. Brackman, M.A. Cartas, and T. Matsuo. 1982. Identification and purification of a protein encoded by the human adenovirus type 2 transforming region. I. Virol. 42: $30-41$.

Hart, R.P., M.A. Mcdevitt, H. Ali, and J.R. Nevins. 1985. Definition of essential sequences and functional equivalence of elements downstream of the adenovirus E2A and early simian virus 40 polyadenylation sites. Mol. Cell. Biol. 5: $2975-2983$. 
Hearing, P. and T. Shenk. 1983. The adenovirus type 5 E1A transcriptional control region contains a duplicated enhancer element. Cell 33: 695-703.

Herrman, C.H., C.V. Dery, and M.B. Mathews. 1987. Transactivation of host and viral genes by the adenovirus E1B 19K tumor antigen. Oncogene 2: 25-35.

Jones, N. and T. Shenk. 1979. Isolation of adenovirus type 5 host range deletion mutants defective for transformation of rat embryo cells. Cell 17: 683-689.

- 1979. An adenovirus type 5 early gene function regulates expression of other early viral genes. Proc. Natl. Acad. Sci. 76: 3665-3669.

Lewis, J.B. and C.W. Anderson. 1987. Identification of adenovirus type 2 early region $1 B$ proteins that share the same amino terminus as do the $495 \mathrm{R}$ and $155 \mathrm{R}$ proteins. J. Virol. 61: $3879-3888$.

Matsui, T., M. Murayama, and T. Mita. 1986. Adenovirus 2 peptide IX genes is expressed only on replicated DNA molecules. Mol. Cell. Biol. 6: 4149-4154.

Melton, D.A., P.A. Krug, M.R. Rebagliati, T. Maniatis, K. Zinn, and M.R. Green. 1984. Efficient in vitro synthesis of biologically active RNA and RNA hybridization probes for plasmids containing bacteriophage SP6 promoter. Nucleic Acids Res. 12: 7035-7056.

Montell, C., E.F. Fisher, M.H. Caruthers, and A.J. Berk. 1984. Control of adenovinus E1B mRNA synthesis by a shift in the activities of RNA splice sites. Mol. Cell. Biol. 4: 966-972.

Nevins, J.R. 1980. Definition and mapping of adenovirus-2 nuclear transcription. Methods Enzymol. 65: 768-785.

- 1987. Regulation of early adenovirus gene expression. Microbiol. Rev. 251: 419-430.

Nevins, J.R. and M.C. Wilson. 1981. Regulation of adenovirus-2 gene expression at the level of transcriptional termination and RNA processing. Nature 290: 113-118.

Nevins, J.R., H.W. Ginsberg, J.M. Blanchard, M.C. Wilson, and J.E. Darnell, Ir. 1979. Regulation of the primary expression of the early adenovirus transcription units. J. Virol. 32: 727733.

Oostrum, J.V. and R.M. Burnett. 1985. Molecular composition of the adenovirus type 2 virion. I. Virol. 56: 439-448.

Pettersson, U. and M.B. Mathews. 1977. The gene and messenger RNA for adenovirus polypeptide IX. Cell 12: 741750.

Pettersson, U. and R.J. Roberts. 1986. Adenovinus gene expression and replication: A historical review. Cancer Cells 4: 37-57.

Sharp, P.A., C. Moore, and J.L. Haverty. 1976. The infectivity of adenovirus 5 DNA-protein complex. Virology 75: 442-456.

Spector, D.J., D.N. Halbert, and H.J. Raskas. 1980. Regulation of integrated adenovinus sequences during adenovirus infection of transformed cells. J. Virol. 36: 860-871.

Venkatesh, L.K. and G. Chinnadurai. 1987. Activation of the adenovirus 2 protein IX promoter by DNA replication in a transient expression assay. Nucleic Acids Res. 15: 22352250.

Virtanen, A. and U. Pettersson. 1985. Organization of early region IB of human adenovirus type 2: Identification of four differently spliced mRNAs. I. Virol. 62: 435-443.

Wigler, M., A. Pellicer, S. Silverstein, R. Axel, G. Urlaub, and L.A. Chasin. 1979. DNA-mediated transfer of the adenine phosphoribosyl-transferase locus into mammalian cells. Proc. Natl. Acad. Sci. 76: 1373-1376.

Wilson, M.C., N.W. Fraser, and J.E. Darnell, Jr. 1979. Mapping of RNA initiation sites by high doses of UV irradiation: Evidence for three independent promoters within the left $11 \%$ of the ad-2 genome. Virology 94: 175-184.
Yoshida, K., L. Venkatesh, M. Kuppuswamy, and G. Chinnadurai. 1987. Adenovirus transforming 19-kD antigen has an enhancer-dependent trans-activation function and relieves enhancer repression mediated by viral and cellular genes. Genes Dev. 1: 645-658. 


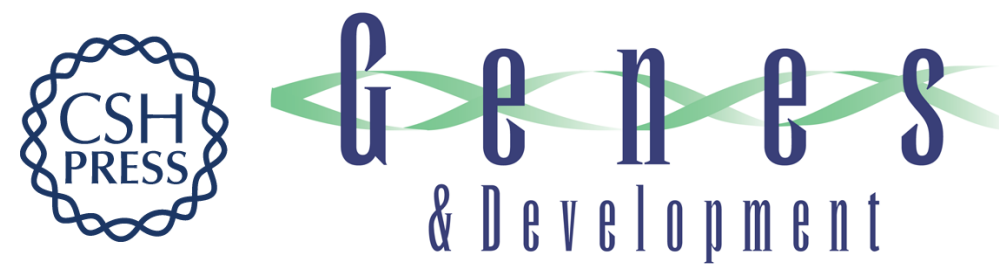

\section{Promoter occlusion prevents transcription of adenovirus polypeptide IX mRNA until after DNA replication.}

L D Vales and J E Darnell

Genes Dev. 1989, 3:

Access the most recent version at doi:10.1101/gad.3.1.49

References This article cites 35 articles, 15 of which can be accessed free at:

http://genesdev.cshlp.org/content/3/1/49.full.html\#ref-list-1

License

Email Alerting

Receive free email alerts when new articles cite this article - sign up in the box at the top Service right corner of the article or click here.

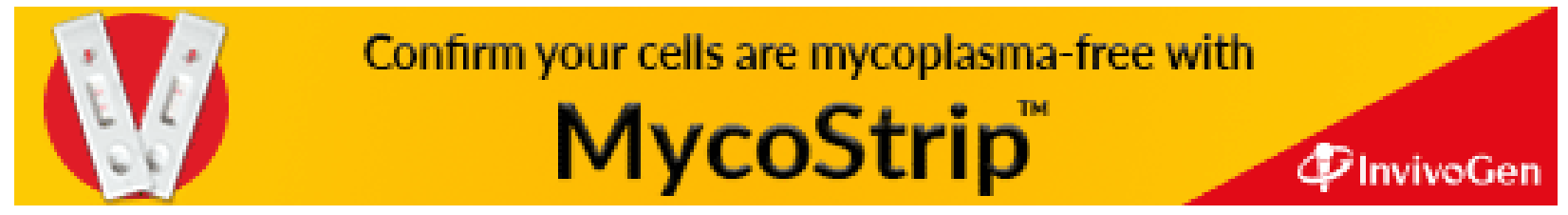

